\title{
Mortality of British coal miners in 1961
}

\author{
F. D. K. LIDDELL \\ Department of Epidemiology and Health, McGill University, Montreal, Canada
}

\begin{abstract}
Liddell, F. D. K. (1973). Brit. J. industr. Med., 30, 15-24. Mortality of British coal miners in 1961. In an earlier enquiry, a sizeable proportion of deaths officially ascribed to coalmining occupations was shown to have been in men who had worked in the industry but not in jobs specific to coalmining, or who had left the mines and taken up other employment. This led to overstatement of mortality among miners, and particularly among face workers.

A new coding of occupations was introduced in 1960, and the present investigation was concerned with all 5362 men aged 20 to 64 who died in 1961 and were recorded as having last worked in a coalmining occupation or for the National Coal Board. The occupation at the time of last employment was determined from colliery records or after special enquiry by medical officers of health, and again was found to be at considerable variance with that on the death certificate. 'Promotion' into coalmining occupations existed in all coalfields and depended on age at death and year of last appearance at work. 'Promotion' to the face was particularly marked; however, more men had been working in the industry than were recorded as in specifically coalmining occupations. The effect of retirement from the coalface to other mining work was investigated.

In occupied miners underground, mortality was less than in all occupied and retired males, substantially so at the face. Miners generally had high rates of deaths from accidents and pneumoconiosis, and low rates for lung cancer. For most other causes, face workers had very low rates, while other underground workers and surface workers had rates below and above the national rates for occupied and retired males. Death rates were higher in Scotland than in the other British coalfields.
\end{abstract}

Past figures on mortality among British coal miners have suggested that it is high among face workers, slightly low for other underground workers, and above average for surface workers; e.g., standardized mortality ratios (SMRs) for 1949-53 in England and Wales were respectively 148, 93, and 107 (Registrar General, 1958b). However, Heasman, Liddell, and Reid (1958) showed that in 1955 the death rate for face workers was inflated by inaccurate occupational descriptions by informants and because of the coding convention. Although there was also some corresponding overstatement in the national census, the authors concluded that the mortality rate of face workers was in fact less than that of other underground workers whose rate was, in turn, less than that for surface workers. They also felt that the death rate for all miners in 1955 was not greater than the national rate for all males. However, other possible sources of error included the convention of relating deaths to the last occupation and inadequacies in age standardization (Liddell, 1961). The Registrar General (1958a, p. 94) accepted that there was a considerable tendency for the occupation of a former miner to be incorrectly recorded, and the simpler classification of occupations introduced in 1960 abolished the convention whereby men described simply as 'coal miners' were assigned to the category of face workers.

This paper reports a study of deaths in 1961 along lines similar to those followed by Heasman and his colleagues (1958), but with two important refinements. First, a sample census of the mining industry 
(Liddell, 1973) provided accurate denominators for death rates of occupied miners. Secondly, information on occupations in 1952, from the records of the pensions scheme introduced at the start of that year, allowed a first examination of the convention over occupations. In addition, various methods of age standardization were used.

\section{Material}

For all deaths registered in 1961 of men aged 20 to 64 in mining occupations or thought to have been employed by the National Coal Board (NCB) the Registrars General of England and Wales and of Scotland provided identity, age, occupation, and cause of death together with any other available relevant details. For each man on colliery books who died in the calendar year 1961, collieries provided details including last occupation, place of death, and occupation in 1952 (or on first employment at that colliery if later). The NCB Pensions Branch informed us of deaths in the year among men of the relevant ages within the Pensions Scheme, many of whom had been retired, and, where necessary, details were sought from the colliery at which the man had last worked. Where it was not possible to match a certificate of death in 1961 with information obtained from the colliery, and in all cases where a man's last recorded employment was earlier than 1961, enquiries (totalling over 1500 ) were made of the deceased's family through more than $\mathbf{2 0 0}$ medical officers of health. In more than 100 cases where the medical officer of health had been unable to obtain adequate details, a letter was written to the informant if it appeared possible that additional information might be obtained in this way. Well over 800 men were reported in these ways to have worked at specific collieries, who were asked to supply missing information. Meanwhile, some 400 certificates were obtained for deaths at relevant ages reported only from NCB sources.

Occupational information from collieries was provided as reference numbers in the NCB National Schedule of Occupations, extended to cover under-officials, juveniles, and weekly paid industrial staff. For each of the well over 500 jobs listed, we agreed with the General Register Office (GRO), a translation into the GRO (1960) Classification of Occupations in which the codes for specifically coalmining occupations are:

\section{Coal mine-face workers}

011 Coal mine - other underground workers

012 Coal mine-workers above ground

013 Coal miners (so described), used as far as NCB information was concerned for three juveniles whose specific work could not be determined.

The study embraced 5362 deaths (Table 1), of which 4212 had been coded 010 to 013 . For England and Wales, agreement with the official figures, taken as one-fifth of registrations in the years 1959-63 (Adelstein, 1967), is seen to be close.

\section{Recording of occupation on death registration}

Table 2 shows the actual occupation (as determined by enquiry) against the occupation code on the death certificate for all 5362 deaths. The information
TABLE 1 The Deaths Studied

\begin{tabular}{|c|c|c|c|c|}
\hline \multirow{2}{*}{$\begin{array}{c}\text { Occupation } \\
\text { code } \\
\text { on death } \\
\text { certificate }\end{array}$} & \multicolumn{3}{|c|}{$N C B$ enquiry } & \multirow{2}{*}{$\begin{array}{c}R G \text { of } \\
\text { England } \\
\text { and Wales }{ }^{2}\end{array}$} \\
\hline & $\begin{array}{c}\text { Great } \\
\text { Britain }\end{array}$ & Scotland & $\begin{array}{c}\text { England } \\
\text { and Wales }\end{array}$ & \\
\hline $\begin{array}{c}\text { Coalmining } \\
\text { 010-Face } \\
011-O . u / g \\
012-S ' \text { face } \\
\text { 013-n.e.c. }\end{array}$ & $\begin{array}{rl}1 & 674 \\
1225 \\
811 \\
502\end{array}$ & $\begin{array}{r}246 \\
163 \\
81 \\
111\end{array}$ & $\begin{array}{r}1428 \\
1062 \\
730 \\
391\end{array}$ & $\begin{array}{r}1435 \\
1051 \\
698 \\
473^{3}\end{array}$ \\
\hline $\begin{array}{c}010-013 \\
\text { Non-mining }\end{array}$ & $\begin{array}{l}4212 \\
1150\end{array}$ & $\begin{array}{l}601 \\
117\end{array}$ & $\begin{array}{l}3611 \\
1033\end{array}$ & \\
\hline Total & 5362 & 718 & 4644 & \\
\hline
\end{tabular}

'See text for explanations of abbreviations.

One-fifth of the deaths registered in the five years 1959-64. 'Includes 014, i.e., workers below ground not elsewhere classified (n.e.c.).

from the two sources is seen to be at considerable variance. Of the 3131 cases when the occupation was known to be specific to coalmining, nearly $10 \%$ of the death certificates had inadequate descriptions (299 coded 013). A further 240 (8\%) were allocated to other codes: the majority of these men had been 'general workers'. Of men in coalmining occupations underground but not at the face, for only half (717 out of 1497 ) was the code correct; nearly one-third (466) were coded as face workers (010). Of the 525 deaths where it was not possible to get firm information, there was some evidence to suggest that the man's last occupation was in coalmining in $80 \%$, but there was no such evidence in the rest; nearly a half had been coded to face work (010).

For 1078 deaths the last occupation was determined as not specific to coalmining but nevertheless within the mining industry (58 of these 'non-mining' occupations were at the face, 512 elsewhere underground, and 508 on the surface): two-thirds of those at the face and elsewhere underground had been conveyor operators and haulage enginemen (GRO code 174). This is in line with the findings of a sample census of the industry (Liddell, 1973).

Of the 628 deaths where the man's last work was definitely outside the coalmining industry, 338 had been coded 010 to 013 and half of these (166) to coalface work (010).

Although 4212 death certificates were given codes 010 to 013 , the numbers who had actually been following occupations specific to coalmining were 3131 (known definitely), or 3555 if the 424 who had at least probably worked in the industry are included, and at most 3656 , when the 101 doubtfuls (i.e., probably not in the industry) are included. 
TABLE 2

Actual Occupations in Relation to Death-Certificate Records

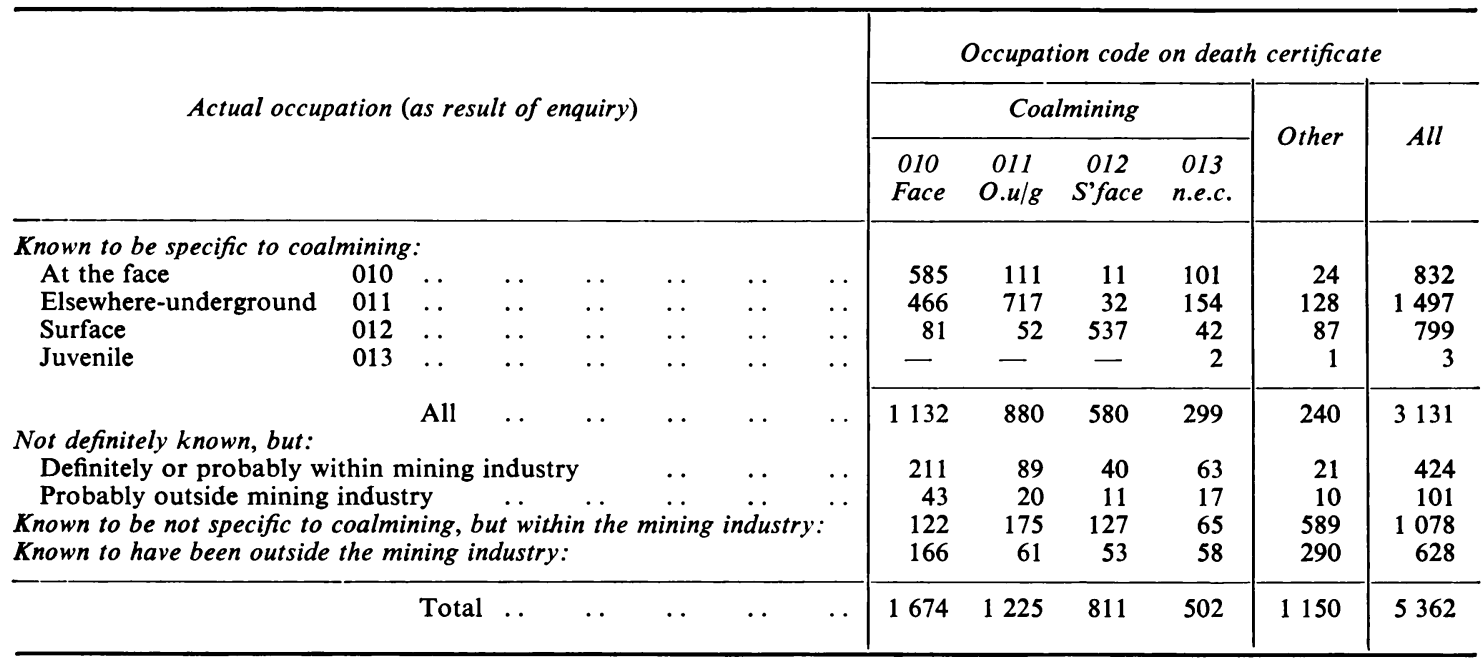

Following Heasman and his colleagues (1958), we express each difference as a percentage of the official figures; this percentage when positive we term 'promotion'. By including the probables, we obtain the likely estimate of promotion, i.e., 100 (4 212$3555) / 4212=15.6 \%$; with upper and lower bounds of $25.6 \%$ and $13.2 \%$.

Promotion was found to vary considerably between coalfields, as shown in Table 3. Apart from Kent, where numbers were small, promotion was greatest in the South Western and Scottish Divisions, followed by West Midlands. Promotion must also be expected to depend on such matters as age at death and year of last appearance at work, and these two factors are themselves associated with the sources of information. Table 3 illustrates these effects.

Table 4 shows actual occupations in relation to age at death. There were clear differences between the age groups. The proportion of deaths in known coalmining occupations was highest for the youngest ages and decreased steadily, while the proportion in occupations not specific to coalmining increased. Further, deaths at ages up to 44 in known coal-

TABLE 3

Promotion into Coalmining in relation to Coalfield, Age, Last Work, and Source of Information

\begin{tabular}{|c|c|c|c|c|c|c|c|c|}
\hline NCB Division & & $\begin{array}{c}\text { Promotion } \\
(\%)\end{array}$ & Age at death & $\begin{array}{c}\text { Promotion } \\
(\%)\end{array}$ & $\begin{array}{l}\text { Year of last } \\
\text { appearance } \\
\text { at work }\end{array}$ & $\begin{array}{c}\text { Promotion } \\
(\%)\end{array}$ & Source of information & $\begin{array}{c}\text { Promotion } \\
(\%)\end{array}$ \\
\hline $\begin{array}{l}\text { Yorkshire } \quad . . \\
\text { Durham } \\
\text { N'land and C'land } \\
\text { N. Western . . } \\
\text { E. Midlands . . } \\
\text { W. Midlands } \\
\text { Scottish . . } \\
\text { S. Western . . } \\
\text { Kent } \\
\text {.. }\end{array}$ & $\begin{array}{l}\cdots \\
\cdots \\
\cdots \\
\cdots \\
\cdots \\
\cdots \\
\cdots\end{array}$ & $\begin{array}{l}+9 \cdot 6 \\
+9 \cdot 9 \\
+13 \cdot 0 \\
+14 \cdot 3 \\
+15 \cdot 2 \\
+15 \cdot 5 \\
+19 \cdot 1 \\
+23 \cdot 3 \\
+37 \cdot 1\end{array}$ & $\begin{array}{l}\text { Under } 45 \\
45-54\end{array}$ & $\begin{array}{l}+6 \cdot 8 \\
+14 \cdot 0\end{array}$ & $\begin{array}{l}1961 \\
1959-60 \\
1952-58 \\
\text { Others }^{1}\end{array}$ & $\begin{array}{l}+8 \cdot 3 \\
+9 \cdot 5 \\
+15 \cdot 2 \\
+49 \cdot 1\end{array}$ & $\begin{array}{l}\text { Notified by colliery } \\
\text { direct } \\
\text { Traced at colliery } \\
\text { only after noti- } \\
\text { fication by } \\
\text { Pension Scheme } \\
\text { Traced at colliery } \\
\text { after enquiry by } \\
\text { MOH } \\
\text { Others }\end{array}$ & $\begin{array}{r}+8 \cdot 2 \\
+12 \cdot 8 \\
+\quad 6 \cdot 9 \\
+53 \cdot 0\end{array}$ \\
\hline All & $\ldots$ & $+15 \cdot 6$ & All & $+15 \cdot 6$ & All & $+15 \cdot 6$ & All & +15.6 \\
\hline
\end{tabular}

${ }^{1}$ Includes those unknown and not followed up because the last employment vas definitely not mining. 
TABLE 4

Actual Occupation by Age at Death

(Numbers of deaths in each age group, and percentage distribution by actual occupations)

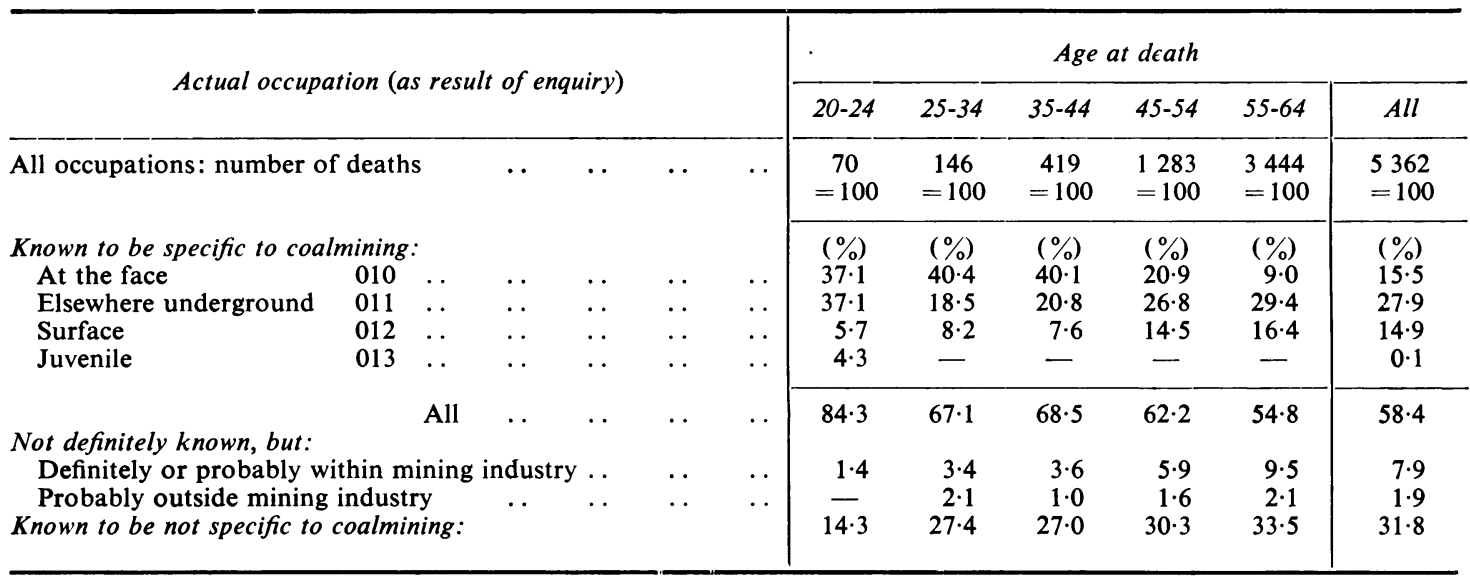

mining occupations were mostly underground, predominantly at the face, whereas in the oldest group there were proportionately fewer deaths of face workers and more of surface workers.
Table 5 gives information on employment in the last years of life. It is restricted to the 3191 men whose last appearance at work was in 1961 and for whom we had information about employment in

TABLE 5

Change of Employment in the Last Years of Life

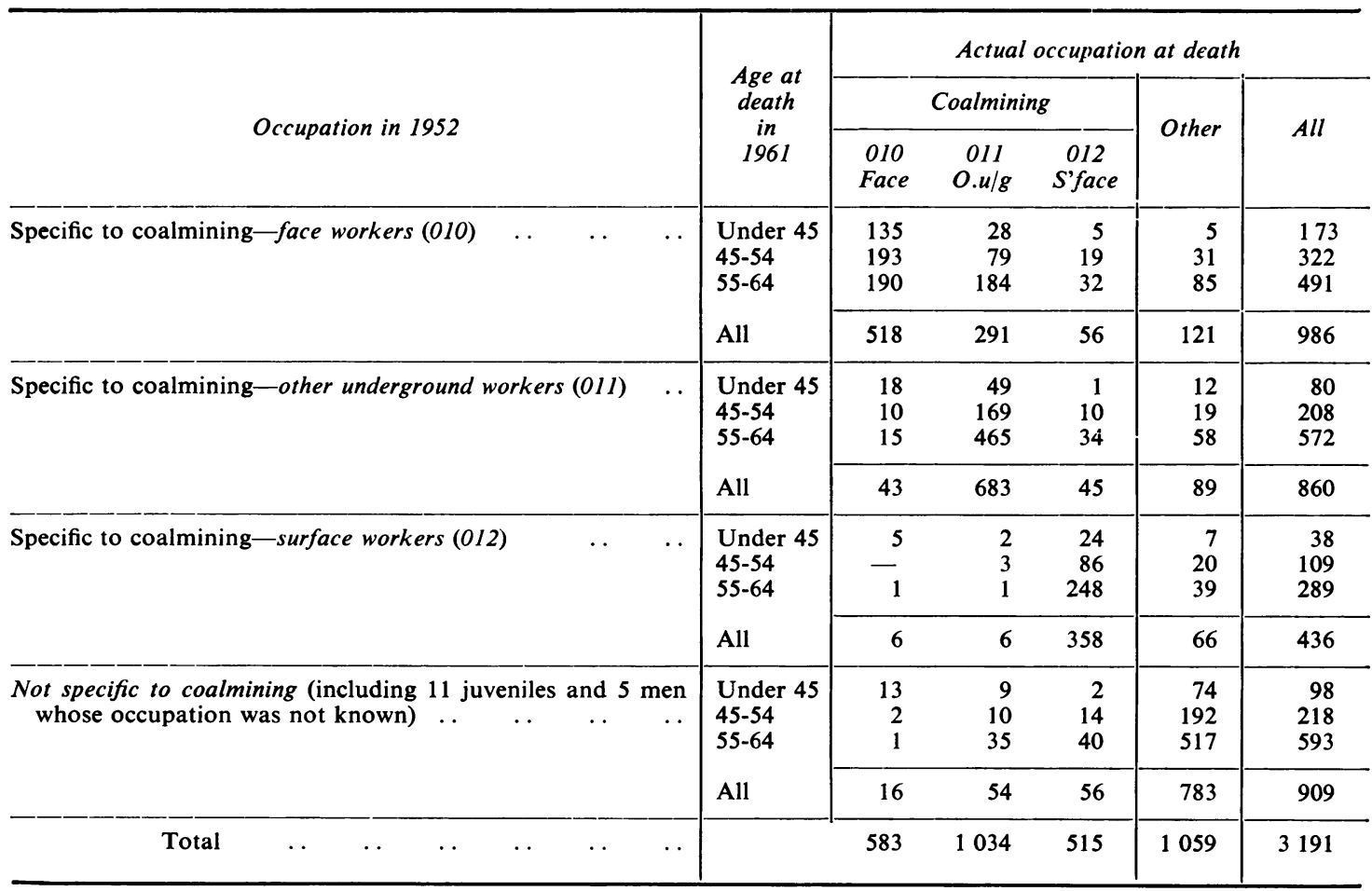


the same industry in 1952. Of the 986 men who had been working at the face in 1952, nearly half were in other occupations at the time of their deaths in 1961. The proportion varied with age, illustrating the well-known move of older men away from the face when work there gets too arduous for them. Of the 860 men employed in 1952 in coalmining occupations elsewhere underground, only 43 had moved to the face in 1961, and, among those who died aged 55 to 64 , there had been considerable movement to occupations not specific to coalmining. Of the 436 men who in 1952 had been in coalmining occupations on the surface, the majority were still in such occupations in 1961, although there had been some move to non-mining occupations. Again, most of those who in 1952 were in occupations not specific to coalmining were in similar occupations in 1961, although of the 98 men under 45 at death, 13 (of whom 11 were juveniles in 1952) had moved to the face. The balance of these various movements was that, although only 583 of the men were employed at the face at the time of death $(18 \%$ of 3191$)$, almost as many again, i.e., $986-518=468(15 \%)$, had been employed there in 1952 .

Table 6 has been prepared for a closer study of 'promotion', both into the industry and to the face. In column (b), the 424 deaths (from Table 2) where occupation was in doubt but probably in the industry have been allocated to definite codes in proportion to the age-occupation distributions of Table 4. That table shows that their ages at death were considerably greater than for those with known occupations, and the adjustment reflects this by allocating slightly fewer deaths to each of the coal- mining codes than would have been expected from the proportions of Table 2, and rather more to others. Thus the best available estimate of promotion into coalmining occupations has been increased slightly to $19 \cdot 3 \%$, as shown in column (c) of Table 6 . Promotion to the face was $46.7 \%$; in other words, nearly half the deaths coded 010 (face) on the death certificate were on this basis incorrectly coded. There was a large shortfall of codes 011 (other underground) and a slight shortfall of deaths coded 012 (surface).

There were 554 deaths where occupation in 1952 was doubtful: in column (d) of Table 6, these deaths have been allocated to definite codes, in proportion to the age-occupation distributions of Table 5. The marked changes in employment from 1952 to 1961 explained part of promotion to the face, reducing it to $12.7 \%$; they explained little of overall promotion into coalmining occupations.

\section{Cause of death}

Table 7 gives the distribution by selected causes of all deaths at ages 55 to 64 , where we knew the year of last appearance at work, and it incorporates information about deaths among all occupied and retired males in England and Wales, 1959-63, at the same ages (Adelstein, 1967). For all 3169 deaths in the enquiry, there was a lower proportion due to malignant neoplasms of lung or bronchus, than in the general population, but higher proportions due to bronchitis and to occupational pneumoconiosis. Marked differences are seen according to last appearance at work. All 3444 deaths at the same ages are shown in Table 8 , by cause, in relation to

TABLE 6

Promotion in relation to Place of Coalmining Work and to Earlier Employment

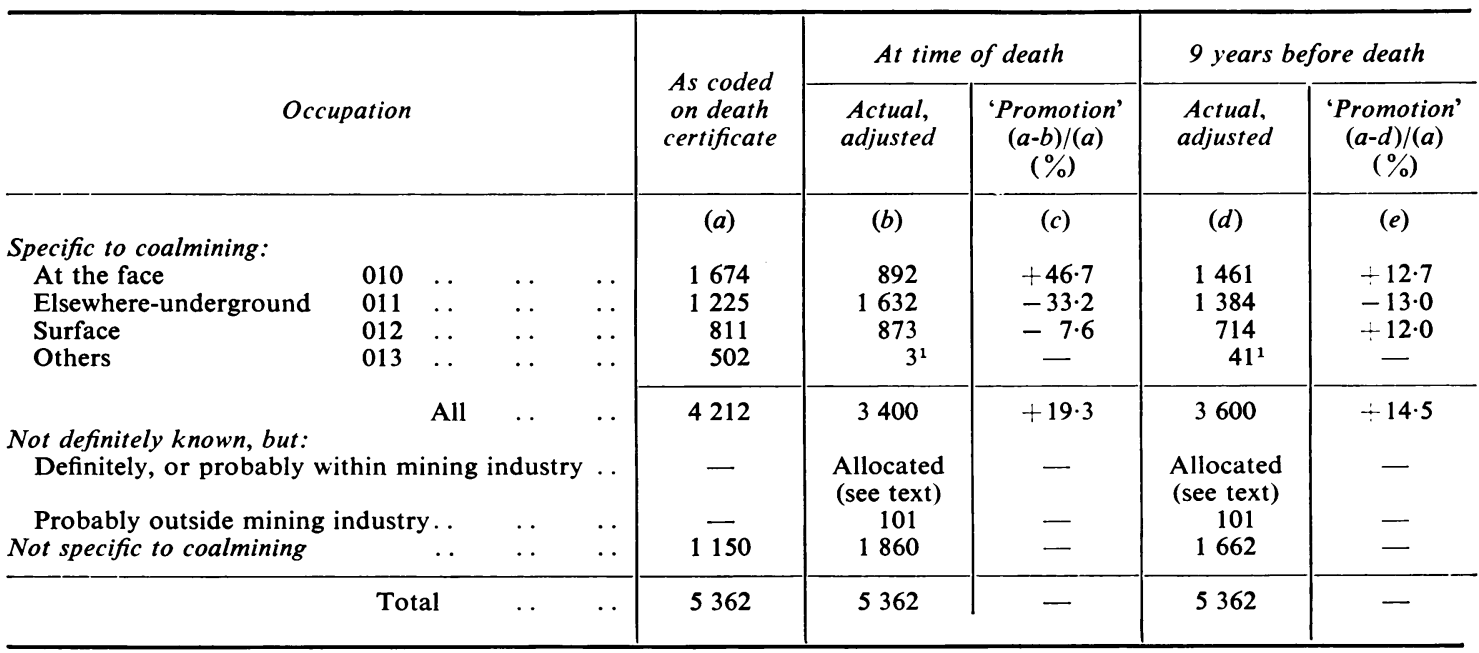

1Juveniles, whose specific occupation was not known. Calculation of promotion is inappropriate. 
TABLE 7

Cause of Death at Ages 55-64 in relation to Last Appearance at Work

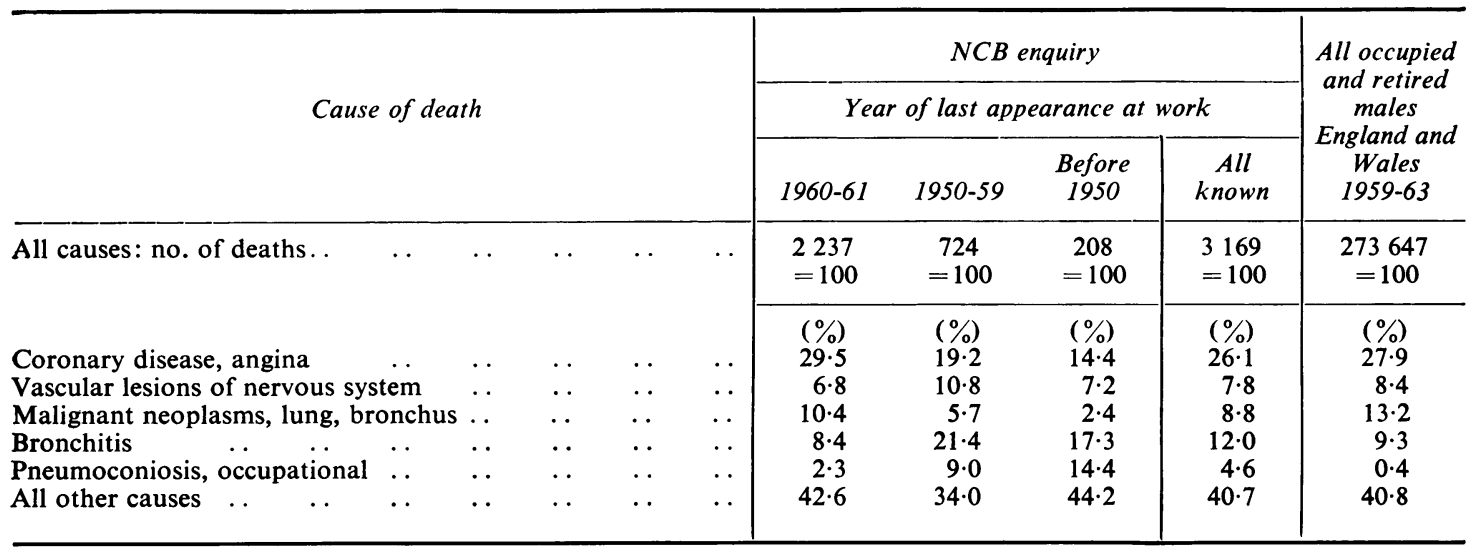

actual and reported occupations. Again marked differences are seen in the various columns. Column (a) is similar to that for all 3169 deaths in Table 7. Columns (b) and (f), relating to deaths not coded to a coalmining occupation, whether or not the man was last working in the industry, are closely similar, with high proportions of deaths from coronary disease (and pneumoconiosis) and low proportions from the other specific causes. Columns (c), (d), and (e), where the man's last work was possibly or definitely outside the mining industry, all show very low proportions of deaths from coronary disease and very high proportions ascribed to bronchitis and pneumoconiosis, and low proportions for the other specific causes.

Occupational pneumoconiosis was the stated cause of death for 2731 males in England and Wales in 1959-63; a little over half were before age 65, the annual average being 289 (Adelstein, 1967). In the enquiry, there were 185 such deaths in England and
Wales (64\% of 289), 85 of them in Wales, 32 and 25 in the North Western and Durham coalfields; and additionally, there were 37 similar deaths in Scotland, bringing the total to 222 . Of these, more than threequarters were at ages 55 to 64 , but one had died before 45 ; again, more than half had not worked for six years, and only one quarter were at work in 1961.

Figure 1 shows cause of death in relation to where it occurred for all 3286 occupied miners for whom information was available. The pattern is generally as might be expected: most deaths occurred at home or in hospital; deaths at work were mainly from coronary disease or accident.

\section{Mortality of working miners}

This section considers the mortality of working miners, based on the 3239 deaths among men whose last appearance at work was in 1961 and who had been industrial workers in the coalmining industry (but excluding weekly paid staff). Denominators of

TABLE 8

Cause of Death at Ages 55-64 in relation to Actual and Reported Occupations

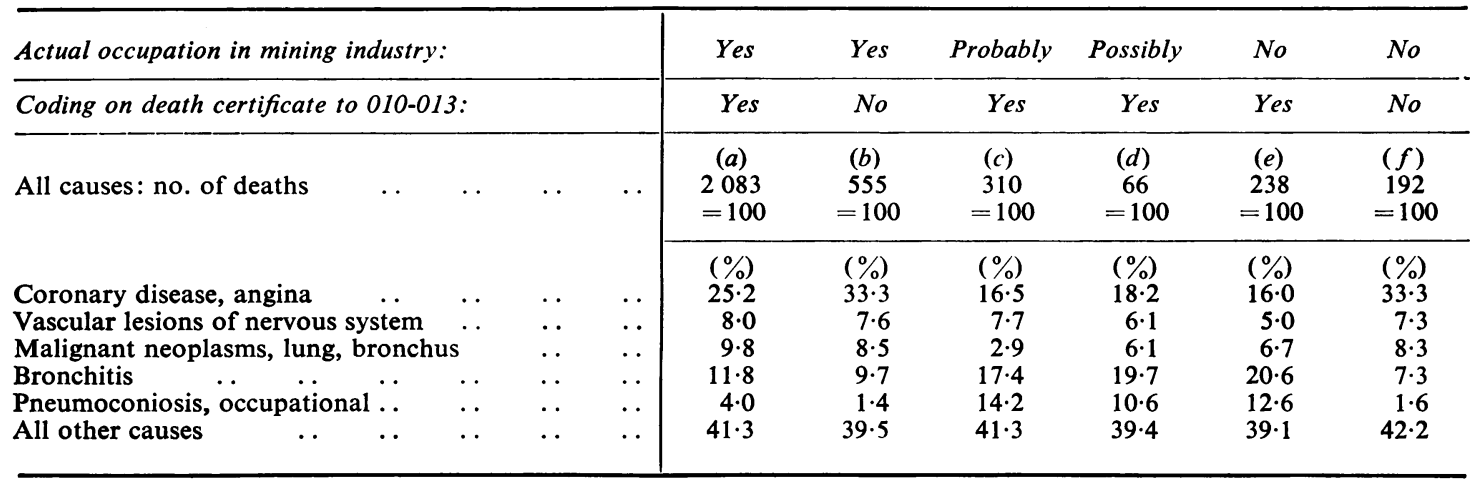




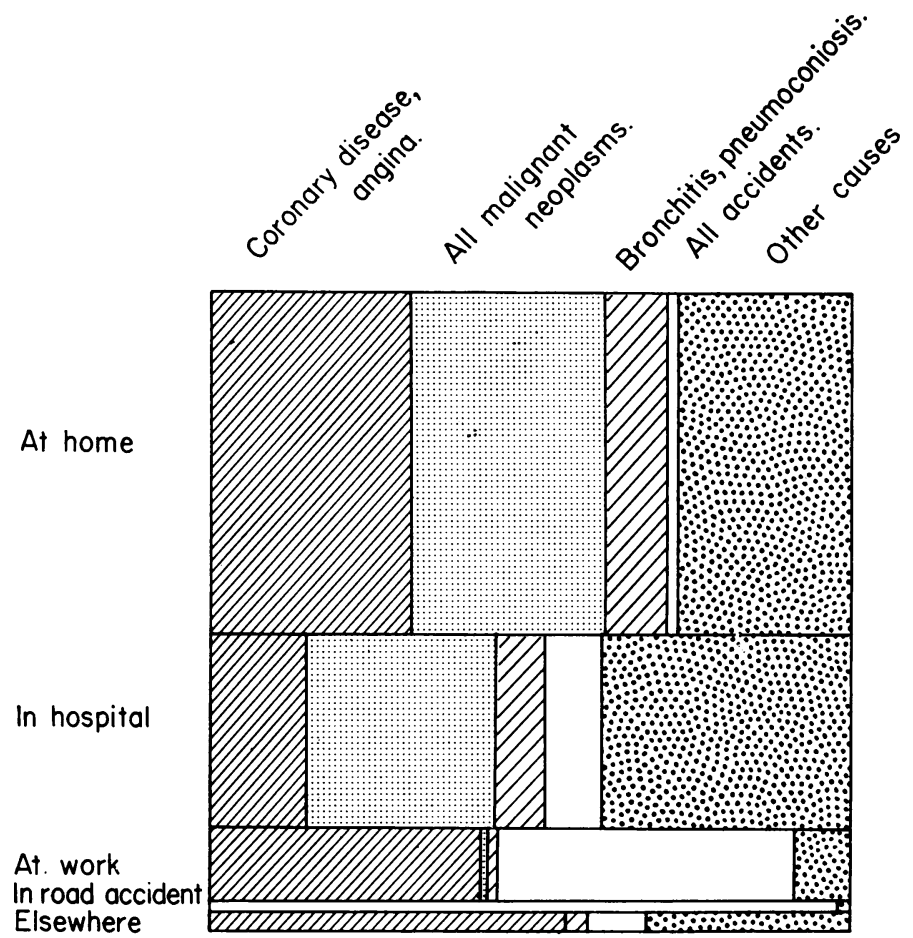

FIG. 1. Place and cause of death.

FIG. 2. Death rates for occupied coal miners, in relation to rates for all occupied and retired males in England and Wales (see text for abbreviations).

FIG. 1

death rates came from a $5 \%$ sample census of the mining industry at June 1961 (Liddell, 1973): the slightly different translations of NCB job reference numbers into GRO occupation codes used for the census were employed throughout this section.

Figure 2 shows age-specific rates of death among occupied men in occupations specific to coalmining and compares them with the rates for all occupied and retired males in England and Wales. At the face, mortality was low in those over 44 . Elsewhere underground, rates were high in the youngest age-groups and low in the oldest but in the middle age range were near to the figures for all occupied and retired males. Surface workers tended to have high rates. Table 9 gives mortality ratios for these three classes of men, standardized (indirect method) against rates (given in the last column) for all occupied and retired males in England and Wales, for all causes and for selected causes (in the RG's grouping). The figures in brackets rank the standardized death rates from highest (1) to lowest in each column.

In Table 10, comparisons are made within the industry for large enough groups. Among occupied miners, under-officials and face workers had low

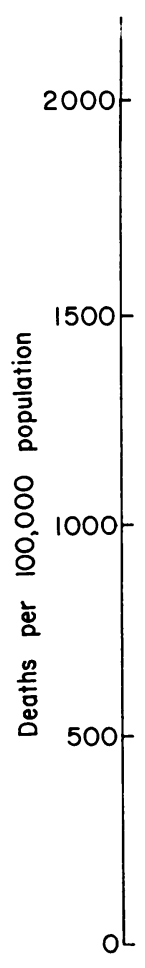

FIG. 2 
TABLE 9

Mortality by Cause among Occupied Coal Miners

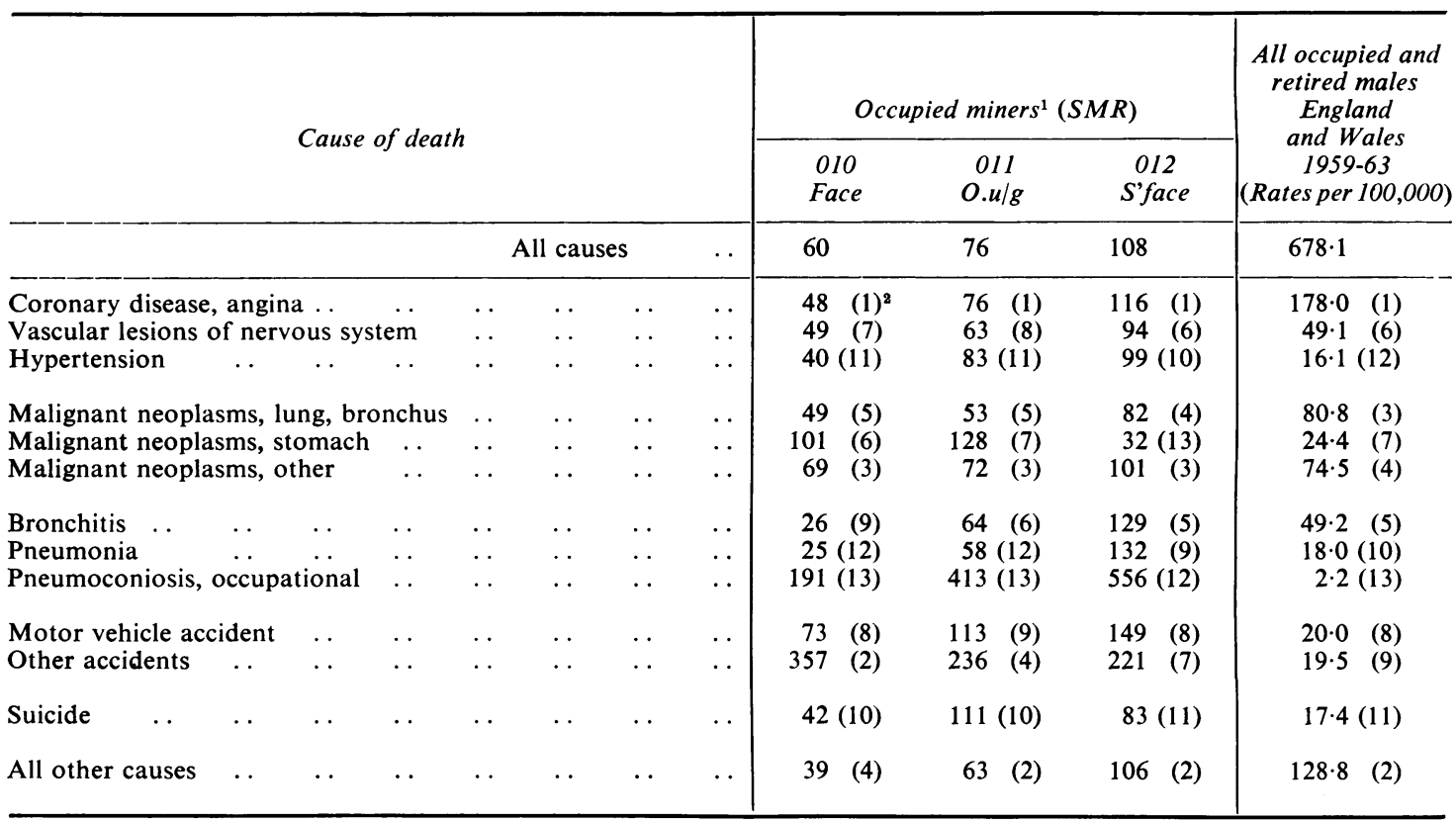

${ }^{1}$ All occupied and retired males, England and Wales $=100$.

${ }^{2}$ Figures in parentheses rank the standardized death rates in each column. These rates can be approximated by multiplying the rate for all occupied and retired males by the SMR.

mortality, and surface workers high rates. This pattern was maintained in all coalfields. There were considerable differences in mortality between coalfields; but, except in Scotland, they were not consistent for each place of work. Mortality was com-

TABLE 10

Mortality AMONG OCCUPIED MinewORKeRS BY JOB AND COALFIELD

\begin{tabular}{|c|c|c|c|}
\hline Actual occupation & $S M R$ & NCB Division & $S M R$ \\
\hline 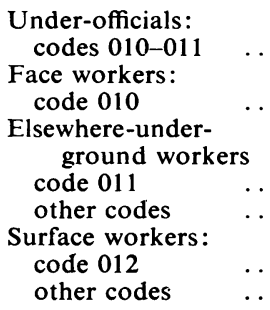 & $\begin{array}{l}102 \\
104 \\
\\
137 \\
127\end{array}$ & $\begin{array}{l}\text { N'land and C'land } \\
\text { Durham } \\
\text { Yorkshire } \\
\text { S. Western } \\
\text { E. Midlands } \\
\text { W. Midlands } \\
\text { N. Western } \\
\text { Scottish }\end{array}$ & $\begin{array}{r}90 \\
91 \\
98 \\
98 \\
102 \\
106 \\
111 \\
115\end{array}$ \\
\hline
\end{tabular}

All occupied mineworkers $=100$.

Groups so small that their SMRs would be unreliable have been excluded. They are: face workers, codes other than 010 ; workshop staff; and the Kent coalfield. pared in collieries classified by degree of face mechanization in 1961, but no patterns emerged.

\section{Discussion}

Comprehensive coverage of deaths where the recorded occupation was specific to coalmining was attained, as is shown by the close agreement of the number of deaths in the enquiry and those expected (Table 1). The nature of the enquiry ensured that mortality among occupied men in the mining industry was also complete. On the other hand, one cannot be certain that all deaths among retired miners whose occupation was not recorded as coalmining were traced: however, over $7 \%$ of the deaths surveyed were not originally reported by Registrars General, largely because they were officially recorded as not in coalmining occupations; and the total of such deaths included in the study was over $20 \%$.

Of 4209 men who were known to have last worked in an industrial job in mining, a quarter (1 078) had been in occupations not specific to coalmining (Table 2). The proportions of such deaths $\left(6 \frac{1}{2} \%\right.$ of those in face occupations, $25 \%$ elsewhere underground, and $39 \%$ surface) are reasonably close to expectation from a sample census of the mining industry (Liddell, 1973) when account is taken of 
differences in age distributions and translations of NCB job numbers into the GRO codes. Nearly half these deaths (489 out of 1078 ) were recorded as in coalmining, probably because informants did not know sufficient about the deceased persons' work. For the same reason, one death in 10 in men in specific coalmining occupations was classed as 'coal miner-so described' (code 013).

The lowest estimate of 'promotion' into coalmining occupations is $13 \%$, but more realistic estimates are rather higher. Expectedly, promotion was less among younger men and those who had not been retired for long, but it was still substantial. No explanation is offered for the considerable differences between coalfields in the extent of promotion.

Of men known to have been employed in the mining industry, 890 deaths were of men whose job was at the face ( 832 in specific coalmining jobs and 58 others) but the occupation was so recorded for $1254(1132+122)$, i.e., promotion was $29 \%$. Again this is the minimum; the most realistic estimate was found to be $47 \%$; it was to some extent balanced by relegation from other places of work. Promotion to the face was much less marked in relation to employment in 1952 (the earliest year for which reliable information could be obtained).

Using the adjusted figures of Table 6 (b) and information from the NCB census (Liddell, 1973), SMRs for occupied and retired coal miners were estimated as follows, with the official figures for England and Wales (Adelstein, 1967) in brackets: 81 at the face $(180) ; 110$ elsewhere underground (94); 179 on the surface (123). Although these SMRs cannot be treated as reliable because of doubts on the populations of retired miners, these would not be likely to have major effects, and it seems clear that the SMR of faceworkers is lowest and that of surface workers highest. This is the gradient found by Heasman and his colleagues (1958) and is in accord with the need for the fittest men at the face, the tendency for older men to move from the face when work gets too arduous for them, and for surface workers to include the less fit.

The distributions by cause of death classified by year of last appearance at work and in relation to actual and recorded occupations show certain interesting similarities; in particular, for those who had been retired at least 10 years and for all three groups of those not definitely occupied in the mining industry. This suggests that these last groups of men probably had been retired for some years and perhaps that they all had worked in the mining industry at some time, even if many of them had worked elsewhere since.

Because the age-specific death rates for occupied men in the three specifically coalmining occupational groups do not stand in the same ratios one to an- other in each age group, mortality ratios will be affected by the method of age standardization (Liddell, 1960). The indirect method is used here: methods weighting by distributions of population rather than deaths give ratios which show a similar gradient but at a higher level: $83,114,131$ by the 'new' method (Liddell, 1960) compared with 60, 76, 108 (Table 9). The basis of calculation is unlikely to affect the main findings. However, comparisons are against the England and Wales mortality, including retired men, so that some SMRs and death rates may be understated in relation to all occupied men.

Clearly, working miners had high mortality from accidents and pneumoconiosis. For face workers 'other accidents' was the second most frequent cause of death, and for others underground the fourth, compared with the ninth for all occupied and retired males. However, despite the high SMRs for pneumoconiosis, it remained the least frequent cause of death among all three groups of miners, except that stomach cancers were very infrequent in surface workers.

For most causes, the gradient, from low mortality at the face to high on the surface, reflects the fitness gradient. That face workers have to be robust is indicated by the particularly low SMRs for pneumonia, bronchitis, hypertension, coronary disease, vascular lesions, and 'all other causes'. The ranking of these causes of death was the same for surface workers as for all occupied and retired males; for both underground groups, pneumonia caused fewer deaths than did hypertension; and bronchitis caused fewer deaths in face workers than did vascular lesions.

Low mortality from cancer of the lung and bronchus was not balanced by neoplasms at other sites (standardized death rates for all cancers were 116 per 100000 at the face, 128 for others underground, and 149 for surface workers, compared with 180 for all occupied and retired males); and it appeared among occupied and retired miners (Table 7). Low death rates from lung cancer have been observed previously for British and American coal miners (Registrar General, 1958a, p. 96; Goldman, 1965; Enterline, 1971). Goldman presented results from the study of Heasman and associates (1958), a survey of respiratory disease in the Rhondda Fach, and a review of mortality in mining and non-mining areas in Wales. He concluded that coal miners' death rate from cancer of the lung was lower than the national rate for men of comparable age; that the trend was not explicable by any factors such as smoking; and that it might be a consequence of the inhalation of coal dust, because of evidence that the incidence of death from lung cancer is lowest among miners whose exposure to coal dust has been highest.

Men in the mining industry performing tasks: 
specific to coalmining had similar mortality to others at the same place of work. Only in Scotland was the mortality of occupied miners consistently higher than for other coalfields at each place of work. No explanation is offered: the differences between coalfields in SMR and in incapacity for work (Liddell, 1973) were not related.

Most of this work was carried out while I was head of Medical Statistics Branch, National Coal Board, and I thank the Board and particularly Dr. J. M. Rogan, Chief Medical Officer, for facilities and encouragement. Sincere thanks are due to the Registrars General of England and Wales and of Scotland, and to Dr. A. M. Adelstein, Chief Medical Statistician, and to Mr. G. F. P. Boston of the Census Division. The excellent co-operation of Medical Officers of Health is gladly acknowledged. Advice was readily available from the Board's Research Advisory Panel on Epidemiology (chairman: Professor D. D. Reid), Dr. Rogan, and Dr. J. S. McLintock, Deputy Chief Medical Officer, NCB. I am very grateful for the essential assistance of the NCB Statistics Department, in particular the late Mr. R. F. George, the late Mr. F. W. Robbins, and Mr. E. C. Foulger, and of Divisional Medical Officers. A special debt of gratitude is due to Mrs. E. D. Baxter, and I wish to thank greatly Mrs.
J. E. Gray and her staff for their vital help. The views expressed are my own and must not be taken as those of any person or organization mentioned above.

\section{References}

Adelstein, A. M. (1967). Personal communication.

Enterline, P. E. (1971). Mortality among coalminers in the U.S.A. Ann. N.Y. Acad. Sci. (In press).

General Register Office (1960). Classification of Occupations 1960. H.M.S.O., London.

Goldman, K. P. (1965). Mortality of coal-miners from carcinoma of the lung. Brit. J. industr. Med., 22, 72-77.

Heasman, M. A., Liddell, F. D. K., and Reid, D. D. (1958). The accuracy of occupational vital statistics. Brit. J. industr. Med., 15, 141-146.

Liddell, F. D. K. (1960). The measurement of occupational mortality. Brit. J. industr. Med., 17, 228-233.

- (1961). Miners' mortality. Incorporated Statistician, 11, 103-109.

- (1973). Morbidity of British coal miners in 1961-62. Brit. J. industr. Med., 30, 1-14.

Registrar General (1958a). The Registrar-General's Decennial Supplement, England and Wales, 1951. Occupational Mortality, Part II, Vol. 1, Commentary. H.M.S.O., London.

—_ (1958b). Ibid., Part II, Vol. 2, Tables, pp. 3-4.

Received for publication February 4, 1972. 